\title{
Standardization of seed testing procedure for seedling evaluation in Bael (Aegle marmelos (L.) Corr.) the endangered medicinal tree
}

\author{
B.Venudevan ${ }^{1}$ and P.Srimathi ${ }^{2}$ \\ Department of Seed Science and Technology ${ }^{1}$, Seed Centre ${ }^{2}$,Tamil Nadu Agricultural University, Coimbatore-3.
}

\begin{abstract}
In any plantation programme, seed is the basic input and evaluation of the quality of collected seed has to be tested before sowing at nursery/plantation, which warrant seed testing. Evaluation of seedling is the first step in seed testing and nursery management which help in identification and separation of abnormalities respectively that could explore and predict the actual planting value at field and the abnormal seedling growth at nursery. These abnormal seedlings are generally discarded from packing stock before transportation of seedling to the planting site. Hence studies were initiated on seedling evaluation for prediction of quality of the seed before sowing both at nursery and germination room. The results would also be much useful in standardization of seedling evaluation techniques in formulation of seed testing procedure for newer inclusion of crops in International and National seed testing rules.
\end{abstract}

\section{Introduction}

Aegle marmelos (L.) Corr., is a popular medicinal tree belongs to the family rutaceae, and is widely known in the Ayurvedic and Siddha systems of medicines to treat a wide variety of ailments. In India, this tree is known as "Bael Tree" and is mostly found in tropical and subtropical region. The tree grows wild in dry forests on hills and plains of central and southern India, Burma, Pakistan, Bangladesh, Sri Lanka, Northern Malaya, Java and Philippine Islands (1). It is medium sized tree having profuse dimorphic branches, alternate, trifoliate, deep green leaves, membranous leaflets, large sweet scented, greenish white flowers, large, globose fruits (2). It flowers from May to July and yields an average of 350-400 fruits (200-250 kg) per tree (3). Almost all parts of the tree are used in preparing herbal medicine (4). The roots are useful for treating diarrhea, dysentery, and dyspepsia. The aqueous extracts of the stem and root bark are used to treat malaria, fever, jaundice, and skin diseases such as ulcers, urticaria, and eczema (5). In pharmacological traits, both the fruit and root showed antiamoebic and hypoglycaemic activities (6). The plant is rich in aegline, marmesin, marmin, and marmelosin the secondary metabolites. The compounds luvangetin and pyranocoumarin, isolated from seeds showed significant antiulcer activity (7). Essential oil isolated from the leaf has antifungal activity (8). The foundation for revitalization of local health traditions (FRLHT), Banglore, India assessed threat status of bael (Aegle marmelos) tree as RET (rare, endangered and threatened) species especially endangered species and importance is being given for mass multiplication through various propagation techniques. It is propagated majorly by seeds and are grown widely in temple gardens as sacred tree and are classified as RET (9).

\section{Materials And Methods}

Fresh and matured bael fruits with greenish yellow colour were collected from plus trees from Coimbatore district $\left(76^{\circ} 57 \mathrm{E}, 11^{\circ} 8 \mathrm{~N}\right.$ and $\left.320 \mathrm{MSL}\right)$ Tamil Nadu, India. Seeds were extracted individually from each of the location adopting wet extraction (soaking the fruit pulp in water for four hours followed by hand cleaning and decanting of extraction water with fruit pulp) technique. The seeds were dried in shade for a week to a moisture content of 10 percent and were pooled for further evaluation. Seeds were non dormant and were sown @ 4 X 100 seeds both in a germination room maintained at $25 \pm 1^{\circ} \mathrm{C}$ and $95 \pm 3 \% \mathrm{RH}$ (10) and in poly bag nursery. Seedlings were allowed to grow without watering in germination room and with watering as once in a day at polypot nursery. After 23 days of germination period, the stage at which there was no further germination, the seedlings were evaluated for their (germination room) germinability/emergence (polypot nursery) potential.

\section{Result And Discussion}

The results revealed that at both the evaluated conditions, 89 per cent of seeds produced normal seedlings (Table.1) that were indicated through the proportionate development of root and shoot. One per cent of the seeds produced in both conditions were abnormal either as single shoot with two roots or single root with two or three shoots. 1.5 per cent of the remaining seedlings had either shoot or root growth or unproportionate growth of seedlings. One per cent of the remaining seedlings were albino seedlings (without chlorophyll) and 5 per cent of seeds were dead. 
Bael belongs to the family rutaceae in which the seed are characterized for single zygotic seed that normally results in single seedling per seed. But in the present study, some of the seedlings germinated from single seed had either two roots or shoots combined with single root and shoot that are abnormal. (11) revealed that in Garcinia indica seeds produce seedling with morphological abnormalities due to polyembryonic nature of the seed which may be, twine and triplet seedlings and also albino and chlorophyll mutant seedlings. (12) in Dalbergia sissoo, (13) in Bombax ceiba in Putranjiva roxburghii , (14), in Nathopodytes nimmoniana, (15), and in Madhuca latifolia, (16) reported that such seedling abnormalities occur due to the interference of polyembryonic nature of seeds. The abnormalities of the seedling were also said to be due to developmental error that occurs during ovary development, fertilization, genetic factors or the mutation (17).

The information on development of these seedlings is essential in germination testing to express the accurate and reproducible results which are meant to be the indicator of true planting value of seed lot (18). ISTA classifies the seedlings abnormalities of germination test as deformed, decayed and damaged seedlings and included them as abnormal seedlings. The twin or triplet seedlings occurred in the present study at both conditions might had been due to polyempryonic nature but might be considered as deformed seedlings (physiological abnormalities) and might be counted as abnormal seedlings that was expressed with disproportionate root to shoot ratio (Table 2). These seedlings should not be included in calculation of germination percentage which is the expression of normal seedling percentage as per ISTA. Among the seedlings, the normal seedling had longer seedling length $(21.4 \mathrm{~cm})$ expressing the proportionate distribution of root and shoot in a comprehensive manner both at germination room and at nursery. But the proportion was erotic and low with twin $(12.1 \mathrm{~cm})$ and deformed seedlings $(3.0 \mathrm{~cm})$, where the reduction was upto by 43 and 85 per cent respectively compared to normal seedling. The other categories of abnormal seedlings observed were seedlings with unproportionate length of root or shoot (deformed seedlings) and the albino seedlings. The albino seedlings were better than deformed seedlings in expression of seedling length but with lesser capacity for longer survival with subsequent growth. Even on transplanting of these abnormal seedlings (twins or triplet and deformed seedlings of germination room) of germination room to nursery, revealed that the survival capacity of twin/ triplet/albino seedlings was found to be less and without the capacity for continued growth. Hence in germination testing, these type of seedlings (twin or triplet or albino or deformed seedlings) should be considered as abnormal seedlings and could not be included in reporting the germination percentage of bael seed lots.

However knowledge on these variations is of much important in genetic improvement and conservation programmes, where research workers on polyembronic seedlings had recommended keeping leading shoot for higher vigour and culling out of remaining shoots at earliest possible to use these seedlings for field planting.

\section{Acknowledgment}

The financial support provided by Department of Seed Science and Technology under UGC Rajiv Gandhi National fellowship for the Ph.D research project is gratefully acknowledged"

\section{References}

[1]. Islam, R., M. Hossain, M.R. Karim and O.I.Joarder, 1995. Regeneration of Aegle marmelos(L.) Corr., plantlets in vitro from callus cultures of embryonic tissues. Current Science, 69: 494-495.

[2]. Purohit, S.S. and S.P. Vyas. 2005. Medicinal Plant Cultivation-A Scientific Approach. (Agrobion. India), pp. 282.

[3]. Mazumder, R., S. Bhattacharya, A. Mazumder, A.K. Pattnaik, P.M. Tiwary and S. Chaudhary, 2006. Antidiarrhoeal evaluation of Aegle marmelos (Correa) Linn. root extract. Phytotherapy Research, 20: 82-84.

[4]. Kala, C.P., 2006. Ethnobotany and ethnoconservation of Aegle marmelos (L) Correa. Indian Journal of Traditional Knowledge, 5: 541-550.

[5]. Nadkarni, K.M.,1954. Indian material Medica, $3^{\text {rd }}$ edn. Popular Book Depot, Bombay, India, pp. 45-49.

[6]. Ponnachan, P.T.C., C.S. Paulose and K.R. Panikar,1993. Effect of the leaf extract of Aegle marmelos (L.) Corr. In diabetic rats. Indian Journal of Experimental Biology,31:345-347.

[7]. Goel, R.K., R.N. Maiti, M. Manickam and A.B. Ray, 1997. Antiulcer activity of naturally occurring pyranocoumarin and isocoumarins and their effect on prostanoid synthesis using human colonic mucosa. Indian Journal of Experimental Biology,35: 1080-1083.

[8]. Rana, B.K., U.P. Sing and V.Taneja.1997. Antifungal activity and kinetics of inhibition by essential oil isolated from leaves of Aegle marmelos (L.) Corr.. Journal of Ethnopharmacology.57: 29-34.

[9]. Sampathkumar, K.P., M. Umadevi, Debjit Bhowmik, Durgesh Mohan Singh and A.S. Dutta, 2012. Recent trends in medicinal uses and health benefits of Indian traditional herbs Aegle marmelos. The Pharma Innovation, Vol. 1 No. 4, 57-65.

[10]. International Seed Testing Association. 2010. International Rules for Seed Testing: edition 2010. ISTA, Bassersdorf, Switzerland.

[11]. Gunaga, R.P. and R. Vasudeva, 2008. Twin and triplet seedlings in Garcinia indica.J. Non-Timber Forest Products, 15(2): 119-122.

[12]. Kumar, A., H.P. Bhatnagar and C.S. Venkatesh, 1977. Twin seedling in Shisham(Dalbergia sissoo). Indian For., 103: 770.

[13]. Venkatesh, C.S. and C.J.S.K. Emmanuel. 1978. Twin seedlings in Bombax ceiba (Bombacaceae). Indian For.,104: 411-413

[14]. Thapliyal, M., 2004. Twin seedlings in Putrangiva roxburghii. Indian J. For., 27: 43-44.

[15]. Hombe, H.C., P.M. Georgi and R. Vasudeva, 2004. Twin seedling in Nathapodytes nimmoniana Graham (Icacinaceae): an important medicinal plant. J. Non-Timber Forest Products, 11(2):20

[16]. Verma, S.K., B.S. Rana and B.P. Singh. 2009. Occurrence of co jointed twin seedlings in Madhuca latifolia Roxb. Indian For., 135.

[17]. Gogate, P.P., K.K. Shirke, S. Vaibhavi, Shirke, A.D. Rane and S.S. Narkhede, 2012. Twin seedling in Terminalia bellerica: An important medicinal plant in Aurveda. Science Research Reporter, 2(1): 83-84. 
Standardization Of Seed Testing Procedure For Seedling Evaluation In Bael (Aegle Marmelos (L.)

[18]. www.agriquest.info 
Table 1. Seedling evaluation under germination testing

\begin{tabular}{|c|c|c|c|c|c|c|c|c|}
\hline \multirow{3}{*}{$\begin{array}{l}\text { Places of } \\
\text { germination } \\
\text { evaluation }\end{array}$} & & \multicolumn{7}{|c|}{ Seed quality Characters } \\
\hline & $\begin{array}{l}\text { Normal } \\
\text { seedling (\%) }\end{array}$ & \multicolumn{5}{|c|}{ Abnormal seedling (\%) } & \multirow{2}{*}{$\begin{array}{l}\text { Fresh un } \\
\text { germinate } \\
\text { d seed (\%) }\end{array}$} & \multirow[t]{2}{*}{$\begin{array}{l}\text { Dead seeds } \\
(\%)\end{array}$} \\
\hline & & $\begin{array}{l}\text { Twin } \\
\text { seedlings/Triplets }\end{array}$ & $\begin{array}{l}\text { Albino } \\
\text { seedlings }\end{array}$ & $\begin{array}{l}\text { Deformed } \\
\text { seedlings } \\
\text { (inproper root } \\
\text { shoot ratio) }\end{array}$ & $\begin{array}{l}\text { Damaged } \\
\text { seedlings }\end{array}$ & $\begin{array}{l}\text { Decayed } \\
\text { seedlings }\end{array}$ & & \\
\hline Germination room & 88.0 & 1.0 & 1.0 & 3.0 & 0 & 2 & 0 & 5 \\
\hline Polypot nursery & 90.0 & 1.0 & 0.0 & 0.0 & 0 & 4 & 0 & 5 \\
\hline Mean & 89.0 & 1.0 & 0.5 & 1.5 & 0 & 3 & 0 & 5 \\
\hline
\end{tabular}

Statistical test not applicable

Table 2. Growth characters of different seedlings under germination testing

\begin{tabular}{|c|c|c|c|c|c|c|c|c|c|c|c|c|}
\hline & & & & \multicolumn{9}{|c|}{ Abnormal seedlings } \\
\hline & \multicolumn{3}{|c|}{ Normal seedlings } & \multicolumn{3}{|c|}{$\begin{array}{c}\text { Twin/triplet seedlings (mean of } \\
\text { all roots/shoot) }\end{array}$} & \multicolumn{3}{|c|}{ Deformed seedlings } & \multicolumn{3}{|c|}{ Decay seedlings } \\
\hline & $\begin{array}{l}\text { Root } \\
\text { length } \\
(\mathrm{cm})\end{array}$ & $\begin{array}{l}\text { Shoot } \\
\text { length } \\
(\mathrm{cm})\end{array}$ & $\begin{array}{c}\text { Seedling } \\
\text { Length } \\
(\mathrm{cm})\end{array}$ & $\begin{array}{l}\text { Root } \\
\text { length } \\
(\mathrm{cm})\end{array}$ & $\begin{array}{l}\text { Shoot } \\
\text { length } \\
(\mathrm{cm})\end{array}$ & $\begin{array}{c}\text { Seedling } \\
\text { Length } \\
(\mathrm{cm})\end{array}$ & $\begin{array}{l}\text { Root } \\
\text { length } \\
(\mathrm{cm})\end{array}$ & $\begin{array}{l}\text { Shoot } \\
\text { length } \\
(\mathrm{cm})\end{array}$ & $\begin{array}{c}\text { Seedling } \\
\text { Length } \\
(\mathrm{cm})\end{array}$ & $\begin{array}{l}\text { Root } \\
\text { length } \\
(\mathrm{cm})\end{array}$ & $\begin{array}{l}\text { Shoot } \\
\text { length } \\
(\mathrm{cm})\end{array}$ & $\begin{array}{c}\text { Seedling } \\
\text { Length } \\
(\mathrm{cm})\end{array}$ \\
\hline $\begin{array}{l}\text { Germination } \\
\text { room }\end{array}$ & 10.5 & 11.6 & 22.1 & 6.8 & 5.9 & 12.7 & 3.8 & 2.1 & 5.9 & 8.9 & 8.0 & 16.9 \\
\hline $\begin{array}{l}\text { Polypot } \\
\text { nursery }\end{array}$ & 9.8 & 10.9 & 20.7 & 6.5 & 5.1 & 11.6 & 0 & 0 & 0 & 7.1 & 6.3 & 13.4 \\
\hline Mean & 10.1 & 11.2 & 21.4 & 6.6 & 5.5 & 12.1 & 1.9 & 1.1 & 3.0 & 8 & 7.2 & 15.2 \\
\hline \% Decrea & $\begin{array}{r}\text { e over } n \\
(100 \%\end{array}$ & ormal s & edling & & & 43 & & & 86 & & & 29 \\
\hline
\end{tabular}

